\title{
TMTC1 wt Allele
}

National Cancer Institute

\section{Source}

National Cancer Institute. TMTC1 wt Allele. NCI Thesaurus. Code C105926.

Human TMTC1 wild-type allele is located in the vicinity of 12p11.22 and is approximately $284 \mathrm{~kb}$ in length. This allele, which encodes transmembrane and TPR repeat-containing protein 1 , a mitochondrial integral membrane protein of unknown function. 